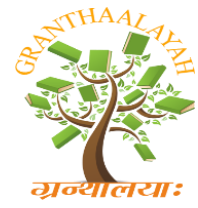

Social

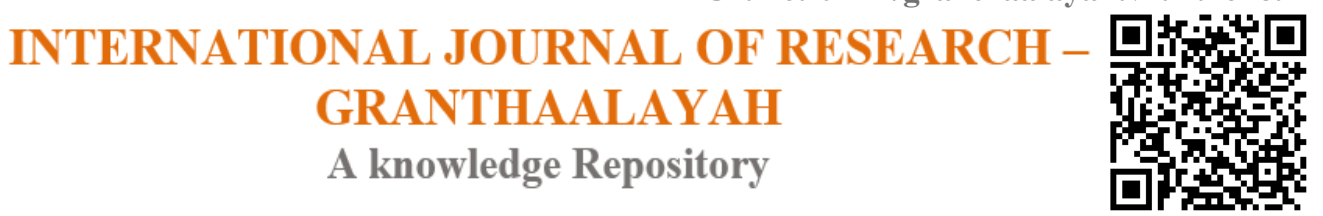

\title{
SUBALTERN STUDIES
}

\author{
Dr. P. Satyanarayana *1 \\ ${ }^{* 1}$ Professor of English, Vaagdevi College of Engineering, Warangal (TS), INDIA
}

\begin{abstract}
This paper explores the roots of the term 'Subaltern'. The form of literature is backed by the history from time to time. The participation of the tribes in revolutions against the then ruling agencies escapes from the history proper. The unwritten languages of the tribes are posing a challenge. They are undermined. The 80 languages have not been brought to the pages of constitution of India. A language spoken by 10, 000 people have to be recognized as a language. There is a dire necessity of the study of folklore. In the multicultural society there is a need for projecting the life-s style and culture of the tribal population. The human rights speak volumes of betterment and welfare of the tribals on the norms of equality, fraternity and liberty. The evaluation of Subaltern studies has been traced right from the past to the present context in the paper to the extent possible. Mahasveta Devi's visison is presented along with illustrations of her reasoning. The need for emergence of trends is emphasized in view of the humanitarian outlooks. The Telangana and Andhra Pradesh states are taken up for tracing the subaltern element with a few episodes emanating from history and folklore. Thus the retrospects and the prospects gauged in the paper will justify the Subaltern Studies.
\end{abstract}

Keywords:

Subaltern Studies; tribes; language; multicultural society.

Cite This Article: Dr. P. Satyanarayana, "SUBALTERN STUDIES" International Journal of Research - Granthaalayah, Vol. 4, No. 4 (2016): 8-12.

\section{INTRODUCTION}

\section{RETROSPECTS}

The term 'subaltern' emerges from Latin 'Sub' to mean 'under' and 'alter' to denote 'other'. Its synonym is 'proletariat'. Some scholars identified the term with British administrative ranks like 'subedari' and 'subaltern'. It was first used by a group of scholars that started publishing the subaltern studies under the areas of the Oxford University Press. The term originates from Antonio Gramsci (1891-1937) an Italian thinker in Marxist tradition. He defined "the subaltern' as somebody who does not have political power and therefore has no voice. Gayatri S. Pivak attributes the term to South Asian Society's colonolised people. Now the term has a wide coverage of groups of people. Ranjit Guha one of the three thinkers, groups the term under 
genealogical study. Gayatri Chakrovarthy is of the same opinion. In 1980s it is viewed as an intrusion of South Asian historiography.

\section{PROSPECTS}

In its evolution the tem covers a large range of people. Julian Wolfrey says, "It contains the groups that are marginalized, oppressed and exploited on the cultural socio-political and religious grounds." Other dimensions are added to it like oppressed and marginalized classes, subjugated people subjected to gender discrimination of lower working classes. According to G.N.Devy, it is that aesthesis, a realization of material reality crystallized into a knowledge about the world. Nearly eighty more languages of 10,000 and more speakers are under oppression, and it is the onerous responsibility of the writers to give those mute expressions a voice and knowledge. Hence, the need for Subaltern Studies.

Mahasveta Devi, in her inaugural speech delivered on 28-3-199 during the National Seminar on her writings at K.U. Warangal disseminated valuable pieces of information, regarding 'subaltern literature'. She is interested in history, particularly the history of the marginalized tribal populace. "The recent anecdote of emergence and evolution of subaltern literature, she says "the tribals told me very quietly that Alluri Sitarama Raju's statues could be found everywhere, but no statue or memorial plaque for the people who died with him and people who suffered for him, because after his death unthinkable torture came down on those hill people."

Tracing the evidence, she exhorts the writers to pen the actual predicaments under which the tribals of Vijayawada, that side of Salur Agency hills. Even for the sake of Telangana struggle the tribals suffered and paid the price. "As such the entire tribal world" she says,'is like some, what shall I say, a great continent that was handed over to us." These tribes handed over to us their culture, their sophistication, their social norms and their social codes like divorce, like nodowry, like widow re-marriages, like men and women staying together then against choosing to marry other partners; things like that.

The precarious conditions turned them otherwise, having no protection from the population on the other side of the forests, the villages and cities. In Telangana, particularly in the district of Warangal the groups of wandering singers, dancers, snake charmers, acrobats, fishermen and drum beaters have under the leadership of social activists organized a meeting in Kazipet in January 2016, to safeguard their art and culture. They are fighting for their identity. The subaltern literature should throw light on these dark corners.

The pressing circumstances of the tribals initiated them into crime. In Midnapore and Purulia districts the stolen goods were exploited by the bordering areas of the forests. The police tortures and kills the tribesmen and mob- lynches them. Between 1977 and 1982, forty three (43) Lodhas of Midnapore were brutally killed.

Foreseeing the future Mahasveta Devi says, "We will enter the 21 st century with this great moral responsibility of carrying the burden of so many de-notified tribes and castes on our hearts, on Indian psyche. So let us all join hands and work together for removing the guilt from our collective conscience," 


\section{NEED FOR THE EMERGENCE OF TRENDS IN "SUBALTERN"}

The tribals are the exponents of 'natural' effects rather than the man made artificial innovations. In other sense, it is primitivists's view of what exists prior to man's independent reasoning and contrivance. It is just because of the fact that they are isolated from civilization. In ethics a primitives lauds the 'natural' or innate instincts and passions over the dictates of reason and prudential forethought. They love life of freedom, innocence and simplicity. Their languages are to be developed with episodes of globalization and research programmes should be evolved in order to enrich their languages giving written forms to them so as to reach them for changes in their primitive culture through subaltern literature. The writers should be in a position to feel the pulse of the tribal people by interacting with them in their own language. For the elite who produce literature, this side of tribal life and ethics should be revealed so as to encourage them to contribute to 'subaltern' literature.

In the words of G.N. Devy, "History is made from the villages and taluka blocks and district divisions by small communities; by people whose names are never recorded in history. History is continuously borne by such people that the basic and central tenet of the subaltern studies may find exercises in all the volumes"

\section{HUMANITARIAN OUTLOOK AND SUBALTERN STUDIES}

As stated earlier in the paper, 80 languages are unexplored in a country like India with 10,000 population each. We are running the risk of a sheer neglect of our fellow beings. On the other hand we are not going to enlist co-operation from the tribes for making good their lives by tapping the resources that lie beneath the hills and forests for the economic development of the country. An effort should be continued to efface the term "marginalised" by our mixing with the tribes for convincing attitude to be promoted among them from the side of the 'artificial' sphere of economic progress of which the citizens are known for.

The journalists should bring to light the life styles of the tribals and record the voices of the people for the linguists to study them for enlarging them into languages proper to be listed under the recognized languages. The research and development projects should cater to the needs of the ungraphed or unwritten languages of the tribals. The international phonetic script can be used for the systematic study of the languages. Tourism development should aim at their direct contact with the people of different areas under the blanket of thick forests wherein the tribes dwell.

\section{THE THREE TRIBAL MANIFESTATIONS OF 'SUBALTER'}

Telangana is replete with tribals like Koya, Gondu and other aboriginal sects originated from forest areas. The history of these tribes does not come into focus. Journalists and writers are expected to explore the dark corners. Subaltern Studies is an area which needs enormous expansion. The cause of Jhats is highlighted recently. But it was after a united struggle. Still the backward tribes never understand the ways to conduct a campaign as an eye-opener to the political authorities. But their very existence as tribes might have seen historical tragedies which went into the abyss of the past .No recorded history is possible. The administrative wings visit these remote areas only in search of natural wealth of resources to cater to the needs of scientific 
age .But these tribes have built up their own systems of knowledge and withstood the political upheavals as well as natural calamities reaped on them from time to time.

The historical struggle of Sammakka and Sarakka against the Kakatiya rulers nine hundred years ago is the manifestation of the warring spirit of the tribes against selfish rulers. Sammakka was a deft warrior and she was reckoned as one with the velour of 'Ekaveera'. Ekaveera was the royal deity of Kaktiya dynasty. Hence, the same reverence was given to the tribal women warriors. Their funeral ashes were revered by the royal dynasty itself. The daughter Sarakka was also the martyr. She too valorously fought against the royal forces sent by PratapaRudra who insisted the tribals to pay the taxes in the time of a heavy drought in the forest area. Drenched in the stream of blood on account of the attack, Sammakka ran to the heights of Cilkala Gutta, a mountain which lies at the north east side of the battle field. She disappeared there. Her beauty aid, Kumkum csket was found under a tree called Naga Vriksha. She was the maternal sister of Koya tribes. The folklore provides us with the historical facts.

A similar unexplored area of Subaltern Studies is also found in the southern Indian area of Tamilnadu. In the first century A.D. there lived 'Ambigamayi Amman', a girl. She adopted Buddhism when she was eleven. She went against her arranged marriage at thirteen. She sat under a neem tree and meditated. The practical benefit she promoted to the people of her times was the awareness of health principles, cleanliness of the surroundings and herbal drug treatment. The use of antiseptic herbs and insect killing smokes was her contribution. She pleaded for light and liquid form of diet during epidemics and encouraged the rich to open 'Ganji' centers, wherefrom the food was to be distributed free of cost. After her 'Nirvana', the demise, her funeral ashes were smeared by the people on their foreheads out of reverence. Even now in Telangana and Andhra Pradesh a patient suffering from small-pox is asked to rest on the neem leaves for curing effect.

A certain tribal gods are of a recent origin too. This episode is only fifty years old. One Sri Keval Kishan of Jogipeta, Medak district, emerged a people's leader out of Andhra Maha Sabha. He carried out land distribution movement and fought against the land lords for the rights of the native people. He was successful in achieving permanent rights of the tribal people over the lands distributed. The landlords killed him by running a loaded lorry over his motor- byke from rear side unawares.

The three subaltern episodes prove to be the actual struggles of the tribes. The historical truth is over shadowed by spirituality and faith. It is the onerous responsibility of the writers to reflect the scene as a historical phenomenon. We are not expected to keep away our brethren from humanitarian consideration. Hence, there is a need for continuous efforts in 'Subaltern Studies'. (Source: An essaypublished by Sri Mallepally Laxmaiah, Social analyst in "SAKSHI", a Telugu Daily dated 25-2-2016.)

\section{CONCLUSION}

Subaltern Studies have historical background. Folklore study will add to the pages of historical facts. The amelioration of tribal life- style aims at humanitarian outlook. Liberty equality and fraternity should be shared with these unrecognized tribes, in order to attain the values enshrined 
in the constitution of India. The Government should take the literary study as a project. Tribal languages should be enlisted as the recognized ones with the linguistic projects to be launched. There is an enormous scope for research and development of Subaltern Studies.

\section{REFERENCES}

[1] Das, B. K. Twentieth Century Literary Criticism, Fifth Edition, New Delhi, Atlantic Publications 2007.

[2] Gayatri Spivak's Interview in U. SA. Journal Polygraph 1980.

[3] Guha, Ranjit.Ed. Subaltern Studies, Vol. VII, Oxford, 1982.

[4] Habib M.A. History of Literary Criticism, From Plato to Present Day: Madem: Blackwell Publications 2005.

[5] K. J. E. S journal Vol 18/1996, Kaktiya University, Warangal,(T.S), India, Department of English Publications 1998. 